\title{
Considerações sobre a Avaliação da Durabilidade de Revestimentos de Argamassa com Incorporação de Resíduos por Meio de Ensaios Acelerados com Ciclos Térmicos
}

\author{
Claudio de Souza Kazmierczak \\ Marlova Piva Kulakowski \\ Feliciane Andrade Brehm \\ Jeferson Alcantara Alves Sentena \\ Leandro Marquetto
}

\section{Introdução}

Tradicionalmente, na especificação de sistemas construtivos para a construção civil são adotadas soluções cujo desempenho já é conhecido. Entretanto, este procedimento vem sendo substituído por especificaçóes baseadas no desempenho requerido para um determinado sistema. A principal motivação para essa mudança conceitual decorreu da necessidade de se viabilizar a comercialização de novos produtos e sistemas, uma vez que o uso de normas e regulamentaçóes prescritivas geram uma barreira para o aparecimento de inovaçóes. Segundo o CIB Report 64 - Working with the performance approach in building (1980), "a abordagem de desempenho é, em essência, a prática de pensar e trabalhar em termos de fins e não de meios”. Essa abordagem considera prioritariamente os requisitos que uma construção deve atender, e não a especificação sobre como ela deve ser construída.

Segundo levantamento histórico realizado por Foliente (2000), o primeiro relato sobre especificaçóes baseados no desempenho, realizado nos tempos modernos, data de 1925, quando o U.S. National Bureau of Standards publicou a "Recommended Practice for Arrangement of Building Codes", na qual se sugere que normas de desempenho sejam adotadas. Apesar dessa 
recomendação, apenas no fim dos anos 60 o U.S. Department of Housing and Urban Development publicou um documento com critérios para projeto e avaliação de sistemas construtivos inovadores. Nas décadas seguintes, órgãos como o International Council for Research and Innovation in Building and Construction (CIB), a American Society for Testing and Materials (ASTM) e a The International Union of Testing and Research Laboratories for Materials and Structures (RILEM) promoveram uma série de conferências sobre o tema. Em 1984, foi publicada a ISO 6241 - Performance standards in building Principies for their preparation and factors to be considered, que lançou a base para as normas de desempenho sobre habitaçóes vigentes atualmente.

Baseada nos princípios da norma ISO 6241, foi lançada, no Brasil, em 2008, a NBR 15.575, que foi revisada em 2011 e intitula-se "Edificaçóes habitacionais - Desempenho". A norma é dividida em 6 partes (Parte 1 Requisitos gerais, Parte 2 - Requisitos para os sistemas estruturais, Parte 3 Requisitos para os sistemas de pisos, Parte 4 - Requisitos para os sistemas de vedaçôes verticais internas e externas, Parte 5 - Requisitos para os sistemas de coberturas e Parte 6 - Requisitos para os sistemas hidrossanitários). Na Parte 4 se enquadram as alvenarias com revestimento de argamassa. Dessa seção, ressaltamos os requisitos listados na Tabela 1, que são aplicáveis a alvenarias.

A abordagem de desempenho pressupóe a definição dos requisitos e das condiçôes de exposição a que o sistema em avaliação estará submetido, para posterior especificação dos critérios e respectivos ensaios de avaliaçáo do sistema. Deste modo, é fundamental que seja realizada uma análise das condiçôes de exposição dos sistemas de revestimento.

Os revestimentos de argamassa estão sujeitos a uma série de solicitações que influenciam na sua durabilidade, tais como a ação do vento durante a cura da argamassa ou ao longo de sua vida útil, vibraçóes, ciclos de molhagem e secagem, ciclos de aquecimento e resfriamento, deformaçôes provenientes de sobrecargas, etc. A Figura 1 (adaptada de BONIN et al.,1999) sumariza as solicitaçóes que podem ocorrer em revestimentos de argamassa. 
Tabela 1. Requisitos da NBR 15.575-4 diretamente relacionados com alvenarias revestidas com argamassa.

\begin{tabular}{|c|c|}
\hline Categoria & Requisitos \\
\hline 6. Funcionalidade & $\begin{array}{l}\text { Interação com portas dos sistemas de vedações verticais externas } \\
\text { e internas. }\end{array}$ \\
\hline $\begin{array}{l}\text { 7. Requisitos } \\
\text { de Segurança } \\
\text { Estrutural }\end{array}$ & $\begin{array}{l}\text { Estabilidade e resistência estrutural dos sistemas de vedação } \\
\text { interno e externo. } \\
\text { Deslocamentos, fissuração e descolamentos nos sistemas de } \\
\text { vedação interno e externo. } \\
\text { Solicitações de cargas provenientes de peças suspensas atuantes } \\
\text { nos sistemas. } \\
\text { Impactos nos sistemas de vedação internos e externos. } \\
\text { Ações transmitidas por impactos. }\end{array}$ \\
\hline 10. Estanqueidade & $\begin{array}{l}\text { Infiltração de água dos sistemas de vedações verticais externas } \\
\text { (fachadas). } \\
\text { Umidade nas vedações verticais externas e internas decorrente da } \\
\text { ocupação do imóvel. }\end{array}$ \\
\hline $\begin{array}{l}\text { 11. Desempenho } \\
\text { Térmico }\end{array}$ & $\begin{array}{l}\text { Adequação de paredes externas. } \\
\text { Aberturas para ventilação. } \\
\text { Sombreamento das aberturas localizadas nos dormitórios em } \\
\text { paredes externas. }\end{array}$ \\
\hline $\begin{array}{l}\text { 12. Desempenho } \\
\text { acústico }\end{array}$ & Níveis de ruído admitidos na habitação. \\
\hline $\begin{array}{l}\text { 14. Durabilidade e } \\
\text { manutenibilidade }\end{array}$ & $\begin{array}{l}\text { Vida útil de projeto dos sistemas de vedações verticais externas e } \\
\text { internas. } \\
\text { Manutenibilidade dos sistemas de vedações verticais internas e } \\
\text { externas. }\end{array}$ \\
\hline
\end{tabular}




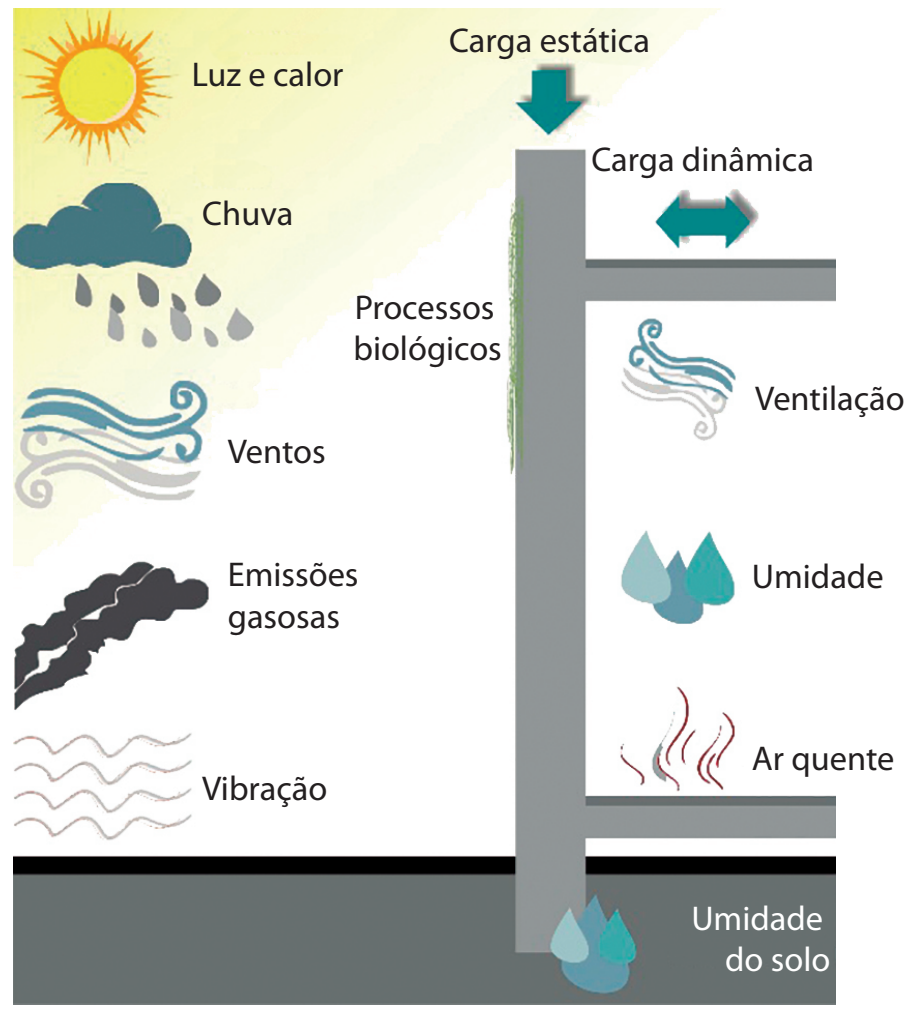

Figura 1. Solicitações nos revestimentos (adaptada de BONIN et al.,1999).

Os processos de deterioração de revestimentos de argamassa podem ser organizados em três grupos: físico-mecânicos, químicos e biológicos. Os processos físico-mecânicos são açôes que usualmente ocorrem sem a interferência humana e podem ter origem no meio ambiente ou no próprio uso da edificação, como a ação do vento e da chuva sobre os revestimentos, a ascensão capilar e a condensação de água, as vibraçóes provenientes do meio externo ou inerentes à edificação, os gradientes térmicos e a ação de raios UV, as cargas estáticas e dinâmicas. Os processos químicos estão relacionados às reaçóes químicas dos constituintes dos revestimentos de argamassa ou às reaçóes de substâncias presentes no ambiente local com os materiais de construção. Os processos biológicos são decorrentes da proliferação de microorganismos nos revestimentos.

Outros fatores também influenciam a durabilidade dos revestimentos, como as características intrínsecas das argamassas, isto é, as propriedades 
dos materiais constituintes, a composição da argamassa, as características do processo de mistura e a forma e condiçôes de execução dos revestimentos.

Ao longo da vida útil da edificação, a deterioração de um revestimento de argamassa pode ainda ocorrer por deficiências relacionadas à estrutura, como recalques diferenciais de fundaçôes ou carregamentos estáticos e dinâmicos acima da capacidade de suporte do revestimento.

Segundo Carazek (2010), é usual que muitos dos fenômenos citados anteriormente ocorram simultaneamente.

A seguir, são discutidos alguns dos principais agentes de degradação dos revestimentos e relacionam-se alguns métodos de ensaio que podem ser utilizados para a avaliação do comportamento do revestimento perante a solicitação.

\section{Penetração de Água}

Em pesquisa realizada pelo IPT, em 1982, foi constatado que 50\% dos problemas patológicos observados em casas térreas e $86 \%$ dos problemas em apartamentos com idade entre 4 e 8 anos classificavam-se como relativos à umidade (PEREZ, 1988). Em outra investigação, realizada em 2004, foi observado que $58 \%$ das manifestaçôes patológicas observadas nos primeiros 4 anos da edificação estavam relacionados à umidade (OLIVEIRA et. al. 2005). Verifica-se-se, portanto, que a umidade é um problema recorrente e responsável por até $2 / 3$ dos problemas patológicos de uma edificação. Também se conclui que tanto sua presença como suas consequências não estão sendo corretamente avaliados na especificação de sistemas de revestimento.

A penetração de água em revestimentos pode ocorrer por capilaridade, por infiltração decorrente da ação da água da chuva, por condensação, umidade acidental ou por pressão de água.

A umidade por capilaridade está relacionada com a capilaridade do revestimento e é regida pela distribuiçáo de poros e pela quantidade de umidade em contato com a alvenaria. $\mathrm{O}$ coeficiente de capilaridade da argamassa pode ser determinado por meio das especificaçóes da NBR 15259/05 - Argamassa para assentamento e revestimento de paredes e tetos - Determinaçáo da absorção de água por capilaridade e do coeficiente de capilaridade (ABNT, 2005). Para se efetuar o ensaio, realizam-se mediçóes de acréscimo de massa em corpos-de- prova de argamassa previamente secos, após os tempos de 10 
e 90 minutos em contato com a água. A partir dos valores obtidos, calcula-se o coeficiente de capilaridade da argamassa. Esse coeficiente, apesar de servir para a comparação da capilaridade entre argamassas (pois é determinado sob condições de cura padronizadas), pode não representar a capilaridade do sistema, composto pelo revestimento aplicado sobre um substrato, em razão da sinergia entre as propriedades dos constituintes, da influência da própria base (que é porosa e influencia fortemente a movimentação da água da argamassa durante sua cura), das condições de aplicação e das condições de cura da argamassa na permeabilidade do revestimento.

A umidade de infiltração decorrente da ação da água da chuva é consequência da ação conjunta da chuva e do vento e é regida pela capilaridade e difusão de umidade do revestimento, além da ação da força de gravidade e da energia cinética das gotas de chuva em frestas. Um método de ensaio para a verificação da estanqueidade de alvenarias à água da chuva é descrito no anexo C da NBR 15.575 - 4. O ensaio consiste na simulação de chuva dirigida a somente uma das faces de um corpo-de-prova (parede de $105 \times 135 \mathrm{~cm}$ ), no intuito de se verificar o tempo necessário até o aparecimento de umidade na face que não foi exposta à água. Outro tipo de ensaio consiste no método do cachimbo, prescrito pelo RILEM Test Method no 11.4 - Measurement of water absorption under low pressure. Por meio desse ensaio mede-se a permeabilidade e a absorção de água da superfície. Entretanto, ele vem sendo criticado por abranger uma pequena área de contato, o que torna o resultado bastante variável, em funçáo de juntas de assentamento ou falhas pontuais na execução do revestimento da alvenaria. Um terceiro método, considerado uma variação do método do cachimbo, está descrito no anexo D da NBR 15.575 - 4. O ensaio procura determinar a absorção de água pela parede, a partir da fixação de uma caixa estanque com abertura voltada para a superfície do revestimento. A caixa é preenchida com água e, após essa etapa, determina-se a absorção de água pela parede em várias idades, calculando-se o volume de água que penetra na alvenaria ao final do período.

A umidade de condensação é a umidade presente no ambiente que, quando em contato com uma superfície mais fria ou por meio da redução brusca da temperatura, condensa e precipita, formando uma película de água na superfície da parede, o que propicia o crescimento de micro-organismos que podem ser prejudiciais à saúde do usuário e promove a deterioraçáo de materiais e equipamentos. Portanto, é desejável que os revestimentos internos 
sejam permeáveis ao vapor de água. Um método de ensaio adotado para verificar a permeabilidade do revestimento ao vapor da água é o descrito na norma europeia NP EN 1015-19. Esse ensaio determina a permeabilidade da argamassa ao vapor, por intermédio de corpos-de-prova posicionados próximos a soluçóes salinas saturadas, que criam duas condiçóes extremas de umidade, uma de $93,2 \%$ de umidade (nitrato de potássio) e outra de 12,4\% de umidade (cloreto de litio). Durante o ensaio, são determinadas as variações de massa do corpo-de-prova.

\section{Penetração de Emissões Gasosas (Gás Carbônico e Cloretos)}

Dentre os agentes que mais afetam a durabilidade de materiais a base de cimento, pode-se citar a ação do dióxido de carbono e de íons cloreto. $\mathrm{O} \mathrm{CO}_{2}$ está presente na atmosfera e é responsável pela carbonatação dos produtos de hidratação do cimento (ANDRADE, 1992). Os íons cloreto são encontrados em aditivos e insumos contaminados, em ambientes marinhos e em determinados ambientes industriais.

A carbonatação consiste em transformar íons alcalinos, como os cátions de sódio, potássio e, sobretudo, de cálcio, em sais de carbonatos desses elementos, pela ação ácida do dióxido de carbono presente no ar (CASCUDO e CARASEK, 2011). Em argamassas, a carbonatação provoca uma diminuição de porosidade e de massa, além de uma redução do volume, devido à retração por carbonatação e, em consequência, um aumento da densidade (CINCOTTO et. al., 2010). Carasek (2010) comenta que as argamassas de revestimento devem possuir a capacidade de absorver deformaçóes, a qual pode diminuir sensivelmente em função da carbonatação. $\mathrm{O}$ estudo do efeito da carbonatação sobre as argamassas pode ser efetuado a partir de ensaios acelerados de carbonataçáo. Esse ensaio consiste em expor corpos-de-prova de argamassa previamente curados a uma atmosfera com determinada concentração de $\mathrm{CO}_{2}$, por um período de tempo que pode chegar a alguns meses. Os teores de $\mathrm{CO}_{2}$ utilizados nos ensaios acelerados têm sido na ordem de até $5 \%$.

A penetração de cloretos é comum em regióes litorâneas, em função da exposição à água do mar direta ou indiretamente (ventos, por exemplo, podem carregar a névoa salina por alguns quilômetros da costa para o interior) (MEHTA e MONTEIRO, 2008). A elevada solubilidade de alguns sais é 
responsável pela facilidade com que são transportados pela água e percolam pelos materiais, sendo os mecanismos de cristalização e dissoluçáo processos complexos e difíceis de controlar (AGOSTINHO, 2008 apud FERREIRA, 2010). Suas consequências são o aumento da higroscopicidade da alvenaria, a degradação da argamassa e a formação de florescências. Um ensaio para a verificação da penetração de cloretos é descrito na RILEM TC 166 - PCD. Embora o ensaio tenha sido desenvolvido para concretos, o método pode ser utilizado em argamassas e é similar ao método de absorção de água por capilaridade. Após selamento das laterais do exemplar, sua face inferior fica em contato com uma solução de $\mathrm{NaCl}$ a $3 \%$, e determina-se a absorção capilar da solução ao longo do tempo.

\section{Processos Químicos e Gases Agressivos}

Os ambientes urbanos e industriais podem apresentar níveis de agressividade elevada para revestimentos de argamassa.

O ambiente urbano pode gerar chuva ácida. Segundo Lima (2011), os óxidos de enxofre, liberados na atmosfera por motores e indústrias, reagem com o vapor de água, produzindo ácido sulfúrico, que é diluído na água da chuva e dá origem à chuva ácida. Esta possui $\mathrm{pH}$ inferior a 4,5 e pode propiciar a dissolução da matriz cimenticia.

O meio ambiente industrial possui microclimas bastante peculiares, podendo resultar em ambientes mais agressivos que o ambiente marinho, em função da contaminação do meio ambiente por substâncias agressivas, como derivados de sulfato, monóxidos e dióxido de carbono na atmosfera (LIMA, 2011).

\section{Processos Biológicos}

Segundo Ferreira (2010), o crescimento de fungos, líquens, algas e outros organismos é comum em fachadas de edifícios, sendo percebido pelo surgimento de manchas escuras com cores de tonalidades preta, marrom ou esverdeada. A presença desses organismos pode gerar a deterioração de argamassas de revestimento, devido ao ambiente ácido que se forma durante o crescimento das colônias.

Segundo Shirakawa, Cincoto e Gambale (2007), os revestimentos de argamassa recém aplicados não são um meio favorável ao crescimento de fungos, em função de sua elevada alcalinidade. Entretanto, após a carbonatação, 
o $\mathrm{pH}$ se reduz, gerando um ambiente propício para o desenvolvimento destes microorganismos. Embora os fungos necessitem de $\mathrm{pH}$ ácido para seu desenvolvimento pleno, em um $\mathrm{pH}$ em torno de 9, o revestimento já apresenta características favoráveis ao crescimento de alguns tipos de fungo. $\mathrm{O}$ desenvolvimento dos microorganismos, entretanto, só ocorre na presença de umidade e pode ser acelerado quando há presença de matéria orgânica.

A RILEM TC 183-MIB Microbial impact on building materials Wheathering and conservation - Techniques applied to the study of microbial impact on building materials e a ASTM D5590-00 Standard test method for determining the resistance of paint films and related coatings to fungal defacement by accelerated four-week agar plate assay descrevem métodos de ensaio utilizados para a avaliação do desenvolvimento de microorganismos em revestimentos.

\section{Cargas Estáticas e Dinâmicas}

Os revestimentos estão sujeitos à ação de cargas estáticas e dinâmicas, provenientes de esforços causados pelo próprio peso, por carga acidental, pela ação do vento, de vibraçóes, de variaçôes dimensionais decorrentes de gradientes térmicos e de variaçóes de umidade. Além disso, frequentemente os revestimentos recebem solicitaçôes decorrentes de deformaçóes na estrutura de concreto, cujo projeto normalmente é realizado sem a avaliação das possíveis consequências em outras partes da construção, como as alvenarias. Fatores como o aumento da esbeltes das estruturas (que gera maior movimentação do edifício quando exposto à ação do vento) e como o aumento da resistência das estruturas de concreto (que diminui a porosidade do substrato de concreto armado, sob o qual é aplicado parte do revestimento de argamassa) colaboram para o surgimento de problemas em revestimentos.

Há um número reduzido de métodos de ensaio específicos para a estimativa do comportamento de revestimentos submetidos a cargas estáticas e dinâmicas, e os poucos normatizados no Brasil analisam situações muito peculiares. $\mathrm{O}$ anexo A da NBR 15.575-4 especifica um método para a determinação da resistência de sistemas de vedação verticais internos e externos às solicitações de peças suspensas. Tal ensaio consiste em submeter os sistemas de vedação vertical a esforços fletores e de cisalhamento solicitantes. Na norma, ainda é citado outro conjunto de ensaios, denominados "Resistência a impactos de corpo mole e Resistência a impactos de corpo duro", que visam a determinar a resistência ao impacto dos sistemas de vedação vertical, por meio da 
ação pendular de um corpo duro e de peso conhecido ao se chocar com o revestimento, ou de um corpo mole, na face externa da alvenaria. Uma forma de se avaliar danos na estrutura interna do revestimento consiste na avaliação da velocidade de propagação de ondas ultrassônicas, cujo método é especificado na NBR 15.630.

\section{Calor e Choque Térmico}

Silva, Gleize e Gomes (2009) comentam que a fissuração de revestimentos em fachadas de edifícios é um dos fenômenos patológicos de maior incidência. $\mathrm{Na}$ grande maioria, as fissuras nos revestimentos de argamassa têm a origem associada à execuçáo do revestimento de argamassa, a solicitaçóes higrotérmicas e principalmente devido à retração hidráulica (BAUER et al, 1997). O consumo de cimento, a distribuição granulométrica dos agregados, o teor de finos, a quantidade de água de amassamento e outros fatores, como a resistência de aderência à base, a espessura da camada e a ação de agentes atmosféricos, são fatores intrínsecos à fissuração. Após a cura, o revestimento está sujeito a variaçóes dimensionais proveniente de gradientes de temperatura, que podem superar a resistência à tração dos revestimentos e propiciar o aparecimento de fissuras.

Alguns ensaios vêm sendo utilizados para analisar a incidência de fissuras em argamassas e a fissuração em revestimentos. No estado fresco, Silva, Gleize e Gomes (2009) fizeram uma adaptação da ASTM C1579 - Standard Method for Evaluating Plastic Shrinkage Craking of Restrained Fiber Reinforced Concrete (Using a Steel Form Insert). O ensaio consiste em acompanhar a pega de argamassa em formas cujo fundo possui restriçóes à retração, que induzem a ocorrência de fissuras. Essas argamassas ficam por 20 horas em uma câmara com temperatura e umidade controladas e com circulaçáo continua de ar, sendo monitorada a fissuração e a ocorrência da primeira fissura visível.

A NBR 13281 (2005) especifica ensaios de retração em barras moldadas em forma não absorvente, que servem para comparação da retração entre argamassas, mas não reproduzem o efeito da absorção de água pelo substrato nem a real evaporação de água para o meio, além de não permitirem a avaliação da retração durante o período de início de pega da argamassa, que pode ser muito expressiva. 
Os resultados dos dois ensaios citados, entretanto, muitas vezes não podem ser extrapolados para revestimentos aplicados sobre substrato de cerâmica vermelha e já curados, sendo, portanto, pouco úteis para estimativas de durabilidade.

Para revestimentos de argamassa aplicados sobre substrato de alvenaria e já curados, o anexo E da NBR 15.575-4 especifica um procedimento de ensaio de resistência ao choque térmico, que consiste em submeter uma parede revestida a dez ciclos de aquecimento, seguidos de resfriamento por molhagem, no intuito de verificar a degradação ou ocorrência de fissuras no revestimento ao longo do processo. Esse procedimento será discutido de forma mais detalhada no item 2.1.

$\mathrm{Na}$ Tabela 2 é apresentada uma súmula de alguns ensaios relacionados à avaliaçáo da durabilidade de revestimentos de argamassa.

Tabela 2. Sumário de ensaios relacionados à avaliação da durabilidade de revestimentos de argamassa.

\begin{tabular}{|c|c|c|}
\hline \multirow{2}{*}{$\begin{array}{l}\text { Condição de } \\
\text { Exposição }\end{array}$} & \multicolumn{2}{|l|}{ Ensaio } \\
\hline & Nome & Norma \\
\hline \multirow[t]{6}{*}{ Umidade } & $\begin{array}{l}\text { Determinação da absorção de água por } \\
\text { capilaridade }\end{array}$ & RILEM TC 116-PCD \\
\hline & $\begin{array}{l}\text { Método do Cachimbo (Measurement of water } \\
\text { absorption under low pressure) }\end{array}$ & $\begin{array}{l}\text { RILEM test method } \\
n^{\circ} 11.4\end{array}$ \\
\hline & $\begin{array}{l}\text { Argamassa de assentamento e revestimento de } \\
\text { paredes e tetos - Determinação da absorção } \\
\text { de água por capilaridade e do coeficiente de } \\
\text { capilaridade }\end{array}$ & NBR 15.259 \\
\hline & Anexo C (estanqueidade à água de SVVE) & NBR 15.575-4 \\
\hline & Anexo D (permeabilidade à água de SVVIE) & NBR 15.575-4 \\
\hline & $\begin{array}{l}\text { Método de ensaio de argamassas para alvenaria } \\
\text { Parte 19: Determinação de permeabilidade } \\
\text { ao vapor de água de argamassas de reboco } \\
\text { endurecidas }\end{array}$ & NP EN 1015 - 19 \\
\hline \multirow{3}{*}{$\begin{array}{l}\text { Emissões } \\
\text { Gasosas }\end{array}$} & Carbonatação & - \\
\hline & & \\
\hline & Deterioração por cloretos & RILEM TC 116-PCD \\
\hline
\end{tabular}


Tabela 2. Continuação.

\begin{tabular}{|c|c|c|}
\hline \multirow{2}{*}{$\begin{array}{l}\text { Condição de } \\
\text { Exposição }\end{array}$} & \multicolumn{2}{|l|}{ Ensaio } \\
\hline & Nome & Norma \\
\hline \multirow{2}{*}{$\begin{array}{l}\text { Processo } \\
\text { Biológicos }\end{array}$} & Microbial impact on building materials: an overview & RILEM TC 183-MIB \\
\hline & $\begin{array}{l}\text { Standard test method for determining the resistance } \\
\text { of paint films an related coating to fungal defacement } \\
\text { by accelerated four-week agar plate assay }\end{array}$ & ASTM D5590-00 \\
\hline \multirow{5}{*}{$\begin{array}{l}\text { Cargas estáticas } \\
\text { e dinâmicas }\end{array}$} & Resistência à compressão e à tração na flexão & NBR 13.279 \\
\hline & $\begin{array}{l}\text { Anexo A - determinação da SVVIE às solicitações } \\
\text { de peças suspensas }\end{array}$ & NBR 15.575-4 \\
\hline & $\begin{array}{l}\text { Anexo B - Verificação da resistência a indentação } \\
\text { - método de ensaio (Impacto de corpo duro) e } \\
\text { ensaio de corpo mole }\end{array}$ & NBR 15.575-4 \\
\hline & $\begin{array}{l}\text { Revestimento de paredes e tetos de argamassas } \\
\text { inorgânicas - determinação da resistência de } \\
\text { aderência à tração }\end{array}$ & NBR 13.528 \\
\hline & $\begin{array}{l}\text { Argamassa para assentamento e revestimento de } \\
\text { paredes e tetos - Determinação do módulo de } \\
\text { elasticidade dinâmico por meio da propagação de } \\
\text { onda ultrassônica }\end{array}$ & NBR 15.630 \\
\hline \multirow[t]{2}{*}{ Calor e Vento } & $\begin{array}{l}\text { Anexo E - Verificação do comportamento de SVVE } \\
\text { exposta à ação de calor e choque térmico }\end{array}$ & NBR 15.575-4 \\
\hline & $\begin{array}{l}\text { Avaliação da fissuração das argamassas (adaptada } \\
\text { da Standart test method for evaluating plastic } \\
\text { shrinkage cracking of restrained fiber reinforced } \\
\text { concrete (using a steel form insert)) }\end{array}$ & ASTM C1579-06 \\
\hline
\end{tabular}

Dentre os diversos métodos de ensaio que, em conjunto, permitem a estimativa da durabilidade de revestimentos, será discutido a seguir o método de avaliaçáo da resistência de revestimentos de argamassa expostos à ação de calor e choque térmico, tendo como base um programa experimental realizado com argamassas de revestimento com adição de resíduos de concreto, aplicadas sobre substrato de cerâmica vermelha, utilizando-se o procedimento especificado no Anexo E da NBR 15.575-4. 


\section{Avaliação da Durabilidade de Revestimentos de Argamassa com Adição de Filer Proveniente da Moagem de Concreto por Meio de Ensaio Acelerado de Exposição ao Calor e a Choque Térmico}

Como parte das metas do subprojeto 2 - Avaliaçáo da durabilidade de materiais, componentes e elementos construtivos inovadores, do projeto FINEP - INOVATEC, foi desenvolvido um método para a avaliação da durabilidade de argamassas com incorporação de resíduos de concreto. A seguir, é apresentado um resumo do método desenvolvido e dos ensaios utilizados para sua validação.

A degradação de determinado material ou componente pode ser estimada a partir de ensaios acelerados. Os ensaios acelerados procuram simular uma determinada condiçáo de exposição que ocorre naturalmente, ao longo da vida útil da edificação, diminuindo o tempo em que a degradação decorrente da exposição irá surgir. Tal situação é obtida ao se diminuir o intervalo de tempo entre as ocorrências das contínuas exposiçóes à determinada solicitação ou por meio do aumento da agressividade associada à determinada condição de exposição. No caso de revestimentos de argamassa sobre substratos típicos de edificaçôes, a simulação da ação do calor e choque térmico reproduz os gradientes de temperatura a que o revestimento de uma parede do sistema de fechamento do edifício pode estar submetido, simultaneamente à ação decorrente da chuva que pode, em pouco tempo, diminuir sensivelmente a temperatura do revestimento, além de propiciar a diminuição da sua resistência mecânica.

A definição dos parâmetros do ensaio acelerado, entretanto, deve ser precedida por um estudo sobre as condiçôes de exposição a que o revestimento estará submetido ao longo de sua vida útil, pois deve haver uma clara relação com as solicitaçóes decorrentes do clima local ao longo de grandes períodos de exposição. Ensaios utilizando parâmetros climáticos de países europeus, por exemplo, simulam a exposição da alvenaria a baixas temperaturas (onde ocorrem situaçóes de congelamento e degelo). Em climas com temperaturas mais amenas, como o que ocorre no Brasil, o ensaio deve simular gradientes típicos entre as temperaturas atingidas durante o dia e a noite, que interagem com o revestimento segundo os processos de transferência de calor, expostos na Figura 2. 


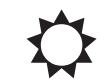

Revestimento no dia

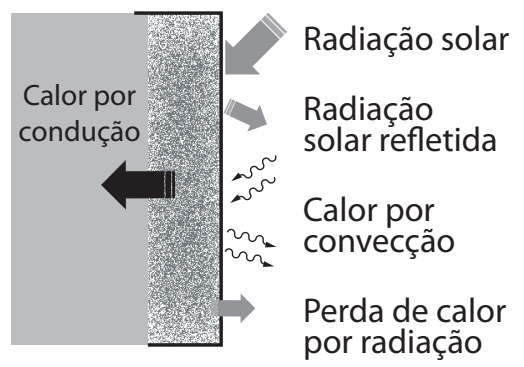

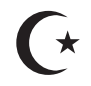

Revestimento à noite

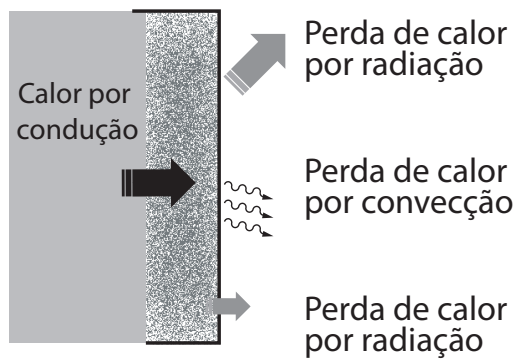

Figura 2. Processos de transferência de calor em revestimentos. Fonte: Esquivel (2009).

Os ciclos de aquecimento e resfriamento realizados em ensaios acelerados tem a função de degradar o revestimento. A deterioração decorrente da ação de ciclos térmicos depende principalmente do coeficiente de expansão térmica (CET) dos materiais constituintes da argamassa, de sua condutividade térmica e do gradiente de temperatura utilizado.

Segundo Schulson, Swainson e Holden (2001), o CET é um parâmetro fundamental para se determinar a tensão interna entre as diferentes fases de materiais à base de cimento e possibilita prever possíveis danos induzidos pelas diferentes dilataçóes térmicas de cada fase. Os constituintes da pasta de cimento possuem diferentes valores de CET. A contração térmica diferencial entre o hidróxido de cálcio $(\mathrm{CH})$ e o silicato de cálcio hidratado (C-S-H) gera tensóes internas no interior da pasta de cimento em estado endurecido, quando submetida a gradientes térmicos. (SCHULSON; SWAINSON; HOLDEN, 2001). A diferença de CET entre os materiais constituintes da argamassa também gera tensóes diferenciais. Valores típicos para CET da pasta de cimento em estado endurecido são de 15 a $20 \times 10^{-6} /{ }^{\circ} \mathrm{C}(\mathrm{MEYERS}$, 1940), enquanto valores para o CET de agregados variam de 5 a $12 \times 10^{-6} /{ }^{\circ} \mathrm{C}$ (GHABEZLOO, 2011). O valor do CET relativo ao substrato sobre o qual a argamassa de revestimento é aplicada também exerce grande influência e varia em função do tipo de substrato. Além das características dos constituintes, 
a porosidade do revestimento também influencia essa propriedade. Qiang Zeng et al. (2011) estudaram o CET em pastas de cimento com ar incorporado e em argamassas com porosidades diferentes. Os resultados mostram que a porosidade tem efeito significativo sobre a deformação térmica e que o CET diminui com o aumento da porosidade.

O gradiente de temperatura a ser adotado no ensaio acelerado precisa ser maior que o observado em situaçôes reais, de modo a aumentar a velocidade do processo de degradação e permitir respostas comparativas entre os revestimentos em pequenos períodos de tempo. Por outro lado, deve haver o cuidado de não se gerar alteraçôes significativas na composição química dos materiais, que podem impedir o estabelecimento de uma correlação entre o ensaio acelerado e o fenômeno real que está sendo reproduzido. Em particular, a temperatura máxima a ser utilizada deve ser estipulada com cuidado. Faure et al. (2011) observaram que a secagem de pastas de cimento em estufa a $80{ }^{\circ} \mathrm{C}$ permite a evaporação da água livre com mínima decomposição de silicato de cálcio hidratado, mantendo as características das pastas. Entretanto, segundo Gallé (2001), temperaturas de secagem entre $60^{\circ} \mathrm{C}$ e $105^{\circ} \mathrm{C}$ resultam em aumento da porosidade capilar, decorrente de estresse capilar, desidratação de hidratos do cimento (etringita, AFm, C-S-H) e geração de microfissuras decorrentes do estresse hidrotérmico interno.

Kim et al. (2003), estudando a condutividade térmica em concreto, argamassa e pasta de cimento, identificaram sete fatores que afetam a condutividade térmica: idade, volume de agregados, quantidade de cimento, tipos de aditivos, fração de finos dos agregados, temperatura e umidade da amostra. Os autores relatam que o volume de agregados e a umidade da amostra são os principais fatores que alteram a condutividade das amostras a base de cimento.

Em ensaios acelerados, pode ocorrer a açáo simultânea de dois ou mais fatores de degradação. Alguns ensaios de durabilidade de revestimentos da envoltória da edificação fazem o resfriamento por molhagem, gerando um choque térmico que simula a ação da chuva em uma fachada aquecida.

$\mathrm{Na}$ Tabela 3, são sumarizados alguns parâmetros de métodos de ensaio acelerado utilizados para a avaliação da durabilidade por gradiente térmico. 
Tabela 3. Parâmetros de alguns métodos de ensaio para avaliação da durabilidade por gradiente térmico.

\begin{tabular}{|c|c|c|c|c|c|}
\hline $\begin{array}{l}\text { Norma/ } \\
\text { Método }\end{array}$ & Equipamento & $\begin{array}{l}\text { Temperatura } \\
\text { mínima }\left({ }^{\circ} \mathrm{C}\right)\end{array}$ & $\begin{array}{l}\text { Temperatura } \\
\text { máxima }\left({ }^{\circ} \mathrm{C}\right)\end{array}$ & $\begin{array}{l}\text { Número de } \\
\text { ciclos }\end{array}$ & $\begin{array}{l}\text { Tempo de } \\
\text { duração do } \\
\text { ciclo }\end{array}$ \\
\hline $\begin{array}{l}\text { NBR } \\
15.575-4 \\
\text { Anexo E }\end{array}$ & $\begin{array}{l}\text { aquecimento } \\
\text { com painel } \\
\text { radiante e } \\
\text { resfriamento } \\
\text { com aspersão } \\
\text { de água }\end{array}$ & $20 \pm 03$ & $80 \pm 03$ & 10 & $\begin{array}{l}\text { aquecimento } \\
+1 \mathrm{~h}+ \\
\text { resfriamento }\end{array}$ \\
\hline $\begin{array}{l}\text { UNE-EN } \\
13687- \\
2: 2002\end{array}$ & $\begin{array}{l}\text { aquecimento } \\
\text { por } 5 \mathrm{~h} 45 \mathrm{~min} \\
\text { e aspersão de } \\
\text { água por } 15 \mathrm{~min}\end{array}$ & $21 \pm 2$ & $60 \pm 10$ & $\begin{array}{l}\text { Especificado } \\
\text { na prEN } \\
1504\end{array}$ & $6 \mathrm{~h}$ \\
\hline $\begin{array}{l}\text { prEN } \\
16306\end{array}$ & - & 20 & 80 & 20 & $24 h$ \\
\hline
\end{tabular}

Obs.: A norma brasileira tem o objetivo de avaliar sistemas de fechamento vertical de edifícios; a norma UNE tem o objetivo de avaliar a compatibilidade térmica de produtos e sistemas de reparo, incluindo pastas, argamassas, concretos e sistemas de proteção superficial; a norma prEN tem o objetivo de avaliar a deterioração de placas de mármore em fachadas.

Observa-se que os gradientes de temperatura recomendados pelas normas citadas não são muito diferentes, variando entre $20^{\circ} \mathrm{C}$ e $80^{\circ} \mathrm{C}$. As normas recomendam a adoção de choque térmico (simulando a ação da chuva sobre uma fachada muito aquecida) e procuram especificar o procedimento de ensaio que melhor represente a situação real de exposição a que o sistema estará submetido ao longo de sua vida útil.

\subsection{Avaliação da Durabilidade de Revestimentos de Argamassa com Filer Reciclado de Concreto por Meio do Ensaio Acelerado de Exposição ao Calor e a Choque Térmico Especificado no Anexo D da NBR 15575-4}

A NBR 15575-4 especifica um ensaio para a avaliação do desempenho de revestimentos verticais de edifícios que pode ser utilizado em alvenarias revestidas com argamassa. $\mathrm{O}$ ensaio consiste em submeter uma parede revestida a 10 ciclos de aquecimento com o uso de painel radiante, seguidos de resfriamento por choque térmico decorrente da aspersão de água. No 
programa experimental utilizado neste exemplo, foram realizadas algumas alteraçóes no método de ensaio previsto na norma brasileira, como a adoção de 40 ciclos de exposição, visando a uma maior degradação do revestimento.

Além da definição do método utilizado para o envelhecimento acelerado, é de extrema importância uma correta especificação das formas de avaliação do dano causado pelos ciclos de envelhecimento acelerado. A NBR 15575-4 especifica como parâmetros de avaliação o "aparecimento de fissuras, trincas, deslocamentos ou outras deterioraçôes em ambas as faces do corpo-de-prova”, e a "avaliação do deslocamento horizontal após $45 \mathrm{~min}$ de estabilização da temperatura superficial em $\left(80 \pm 3^{\circ} \mathrm{C}\right)$ e imediatamente após o resfriamento", ao longo de 10 ciclos de ensaio. A ocorrência de fissuras ou de algum dos demais sintomas de degradação citados é suficiente para que o sistema seja reprovado no requisito durabilidade, segundo a norma. Entretanto, a simples avaliação visual do revestimento e da deformação existente no sistema não fornecem informaçóes sobre as alteraçóes de microestrutura que podem estar ocorrendo ao longo do processo de envelhecimento a que a amostra está sendo submetida, fato que geralmente impossibilita uma análise quantitativa da diferença de desempenho entre os diversos sistemas de revestimento.

Com vistas a permitir uma melhor identificação das eventuais alteraçôes de propriedades do sistema de revestimento em função do ensaio de envelhecimento, é necessário que sejam realizados outros ensaios de avaliação, além dos citados na referida norma. Nesse sentido, serão discutidos a seguir algumas alternativas de ensaios para esse tipo de avaliação.

\subsection{Métodos Propostos para a Avaliação da Degradação do Revestimento de Argamassa}

\section{a. Avaliaçáo da Fissuração nos Revestimentos.}

A NBR 15575-4 impóe como parâmetro de aceitação de desempenho o não "aparecimento de fissuras e trincas", a avaliação da fissuração permite uma comparação mais objetiva para o desenvolvimento de traços de argamassa com incorporação de resíduos, sendo possível avaliar de que modo diferentes materiais e parâmetros de dosagem exercem influência na fissuração de revestimento, seja ao longo do processo de cura ou da vida útil dos revestimentos, esta última simulada pelo ensaio de envelhecimento acelerado. 
Um método proposto para esta avaliação consiste no registro fotográfico da superfície do revestimento, com uso de câmera de alta resoluçáo, e posterior determinação da área fissurada. Esse método permite a avaliação da evolução do nível de fissuração ao longo do tempo e a comparação deste parâmetro entre os diversos sistemas de revestimento utilizados.

\section{b. Determinação da Absorçáo de Água do Sistema Composto pelo Reves- timento Aplicado Sobre a Base de Cerâmica Vermelha.}

Segundo Caré (2008), as modificações decorrentes da ciclagem térmica podem ser constatadas por meio de alteraçóes na porosidade capilar dos revestimentos. O método de ensaio utilizado para a determinação da absorção de água por capilaridade foi baseado no procedimento descrito na recomendação RILEM TC 116-PCD, e consiste na determinação da capilaridade à água por fluxo unilateral no revestimento. Dessa forma, para a realizaçáo desse teste, foram extraídos corpos-de-prova circulares da alvenaria (com diâmetro de $50 \mathrm{~mm}$, e altura correspondente à espessura do revestimento somada à do substrato cerâmico, visualizado na Figura 3a). Esses exemplares foram secos em estufa, tiveram sua lateral selada e posteriormente foram submetidos ao ensaio de absorção de água por capilaridade, por imersão parcial em recipiente com água. Em períodos determinados, os exemplares são pesados e a diferença de massa é utilizada para o cálculo da absorção capilar. Como resultado do ensaio, consegue-se traçar uma curva de absorção capilar, na qual é possível identificar o momento em que a água absorvida atinge o substrato, e realizar um estudo exclusivo da permeabilidade do revestimento. Além da determinação da capilaridade, o ensaio permite uma estimativa do volume total de poros capilares dos sistemas ensaiados. A figura 3 demonstra detalhes do ensaio: 

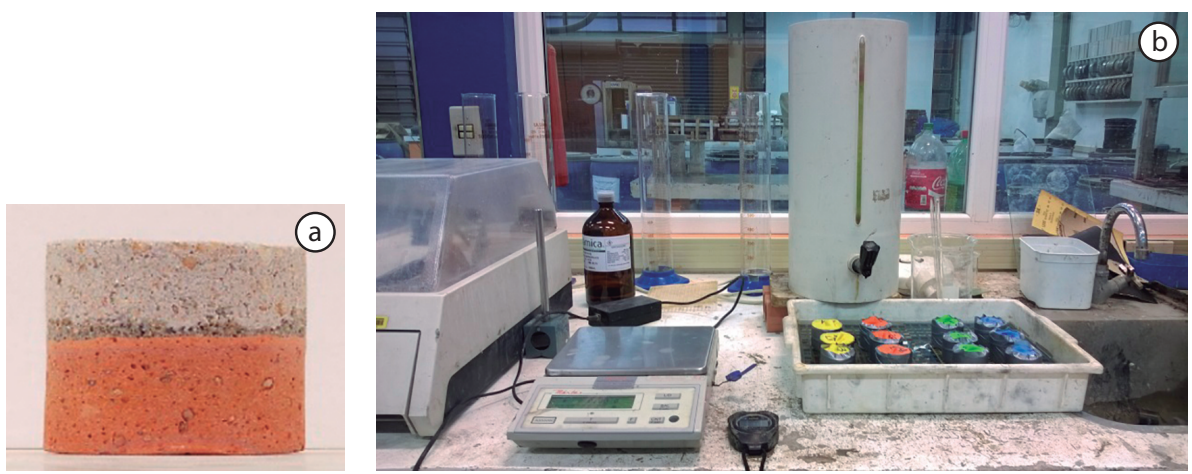

Figura 3. Corpo-de-prova para ensaio de capilaridade (a) e visualização do procedimento de ensaio (b).

Uma variação ao ensaio adotado é o método proposto pelo Anexo D da NBR 15.575-4, que permite a avaliação da permeabilidade à água de sistemas compostos por alvenaria e revestimento. Entretanto, esse método permite a evaporação de água do sistema durante a execução do ensaio e sofre grande influência do preparo da base (chapisco) e do tipo de bloco cerâmico utilizado, sendo impossível avaliar exclusivamente a influência do revestimento.

\section{c. Determinaçáo da Resistência de Aderência à Traçáo e da Forma de Rup- tura por Tração.}

A determinação da resistência de aderência à tração foi realizada segundo as especificaçóes da NBR 13528 (ABNT, 2010). Esse método permite avaliar se a resistência de aderência do revestimento se encontra acima dos parâmetros especificados pela Norma NBR 13749 (ABNT, 2013) (os limites inferiores variam entre 0,2 e 0,3 $\mathrm{MPa}$, dependendo do local e do tipo de acabamento do sistema de vedação vertical), antes e após a conclusão dos ciclos do ensaio acelerado. Também possibilita estimar a perda de aderência ao longo do ensaio. Entretanto, como a resistência de aderência é influenciada por diversos fatores, como as características da argamassa, as características do substrato utilizado e as condiçôes de aplicação de revestimento (como a energia de aplicação e as condiçôes de evaporação de água), é comum ocorrer uma elevada dispersão de resultados, que segundo Carasek (2012) varia entre $10 \%$ e $60 \%$. A autora considera aceitáveis ensaios cujo coeficiente de variação seja igual ou inferior a $25 \%$. A elevada variação dos resultados muitas vezes impede uma análise conclusiva sobre o comportamento do revestimento. 
No programa experimental, foram realizados 18 ensaios em cada sistema, amostragem superior à especificada na norma.

A NBR 13528 (ABNT, 2010) também especifica que a forma de ruptura em cada ensaio de arrancamento seja identificada, considerando que rupturas do tipo coesiva (ocorridas no interior da argamassa ou do substrato) são as mais desejáveis, em detrimento de rupturas do tipo adesiva (em interfaces do sistema), que estão associadas ao maior risco de manifestaçóes patológicas. Desta forma, neste programa experimental, também foi identificada a forma de ruptura de cada teste de arrancamento, por meio de fotografia digital de alta resolução, separação da imagem por escalas de cores e contagem de pixels.

\section{d. Avaliação do Volume de Vazios na Argamassa.}

A determinação do volume de vazios existentes na argamassa de revestimento foi realizada a partir do volume de vazios visualizado em imagens fotográficas digitais de alta resoluçáo de exemplares extraídos do revestimento, validado pelo volume de vazios observado em imagens obtidas com o uso de microscópio eletrônico de varredura (MEV) de exemplares extraídos da mesma argamassa e ensaios de porosimetria por intrusão de mercúrio. $\mathrm{O}$ método adotado consiste na extração de testemunhos do sistema composto pelo revestimento aplicado sobre a base de cerâmica vermelha, no corte transversal dessas amostras, e a posterior análise da quantidade de vazios existente na argamassa e na área de interface entre a argamassa e o substrato, por meio de fotografia digital de alta resolução, separação da imagem por escalas de cores e contagem de pixels.

Outro método utilizado foi a determinação da velocidade de propagação de ondas ultrassônicas, que permite, de forma indireta, avaliar o aumento da porosidade do revestimento em função do aparecimento de fissuras.

\section{e. Determinação da Dureza Superficial por Meio de Durômetro.}

A determinação da dureza superficial tem o objetivo de verificar alteraçôes de dureza decorrentes do processo de deterioraçáo do revestimento devido aos ciclos térmicos. Estima-se que ocorra uma diminuiçáo gradativa da dureza superficial do revestimento submetido ao ensaio de envelhecimento acelerado, embora em algumas situaçóes seja possível ocorrer o inverso, em consequência de carbonatação ou de hidratação da parcela de aglomerantes não hidratados por ocasiáo do início dos ensaios. O método utilizado baseou-se na ASTM D 2240-5 e consiste na determinação da dureza superficial do revestimento com 
Durômetro Shore tipo D. A dureza superficial foi estimada a partir da média aritmética entre 12 determinaçóes na mesma superfície.

\subsection{Programa Experimental, Resultados Obtidos e Discussão}

Foram avaliados quatro tipos de revestimento aplicados sobre um substrato de blocos de cerâmica vermelha. Os revestimentos consistem em uma argamassa no traço 1: 1: 6 (cimento : cal em pasta: agregado miúdo, em volume) diferenciados pelo teor de fíler proveniente da moagem de concreto presente no agregado miúdo. Os aglomerantes utilizados foram o cimento Portland CP II-F-32 e a cal hidratada CH I. Como agregados, foram utilizados uma areia quartzosa, extraída em rio, lavada, com granulometria entre as peneiras $2.4 \mathrm{~mm}$ e $0,075 \mathrm{~mm}$ (considerada como areia de referência)

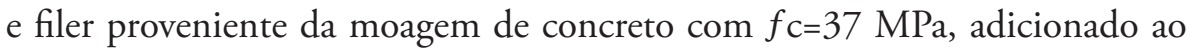
agregado de referência nos teores de 2\%, 4,5\%, 7\% e 9,5\%, em massa. Após 72 horas do preparo do substrato de cerâmica vermelha com chapisco no traço 1: 3, em volume, foi aplicado o revestimento, cuja cura foi realizada em sala climatizada com temperatura de $(23 \pm 2){ }^{\circ} \mathrm{C}$ e umidade de $(60 \pm 10) \%$ por 28 dias. A caracterização detalhada dos materiais e dos resultados dos ensaios realizados pode ser consultada em Sentena (2015).

Como o foco do trabalho foi a avaliação da degradação do sistema de revestimento por meio de ensaios acelerados, um parâmetro inicial para a escolha dos sistemas a serem testados foi a inexistência de fissuras, trincas, ou outras deterioraçóes na face do revestimento, imediatamente após o período de cura, além da existência de uma resistência de aderência à tração, medida segundo especificado na NBR 13528 (ABNT, 2010), superior a 0,3MPa. A avaliação do comportamento dos revestimentos foi realizada antes e depois dos quarenta ciclos de envelhecimento acelerado.

A súmula dos resultados obtidos utilizando-se os métodos descritos é realizada a seguir.

- Após exposiçáo a 40 ciclos de aquecimento por painel radiante e resfriamento por choque térmico por aspersão de água, não foi constatado nenhum dano superficial relacionado na norma de desempenho, como a ocorrência de fissuras, trincas e deterioraçôes superficiais visíveis. Sob 
o ponto de vista do desempenho, segundo a referida norma, todos os revestimentos foram aprovados.

Entretanto, é lógico estimar que os revestimentos com argamassa e resíduos de concreto devem ter sofrido deterioração, embora esta não seja possível de ser constatada a partir da análise visual da superfície do revestimento.

- Na figura 4, é possível visualizar os gráficos de absorção de água por capilaridade do sistema composto pelo revestimento aplicado sobre a base de cerâmica vermelha, antes e após o ensaio acelerado.
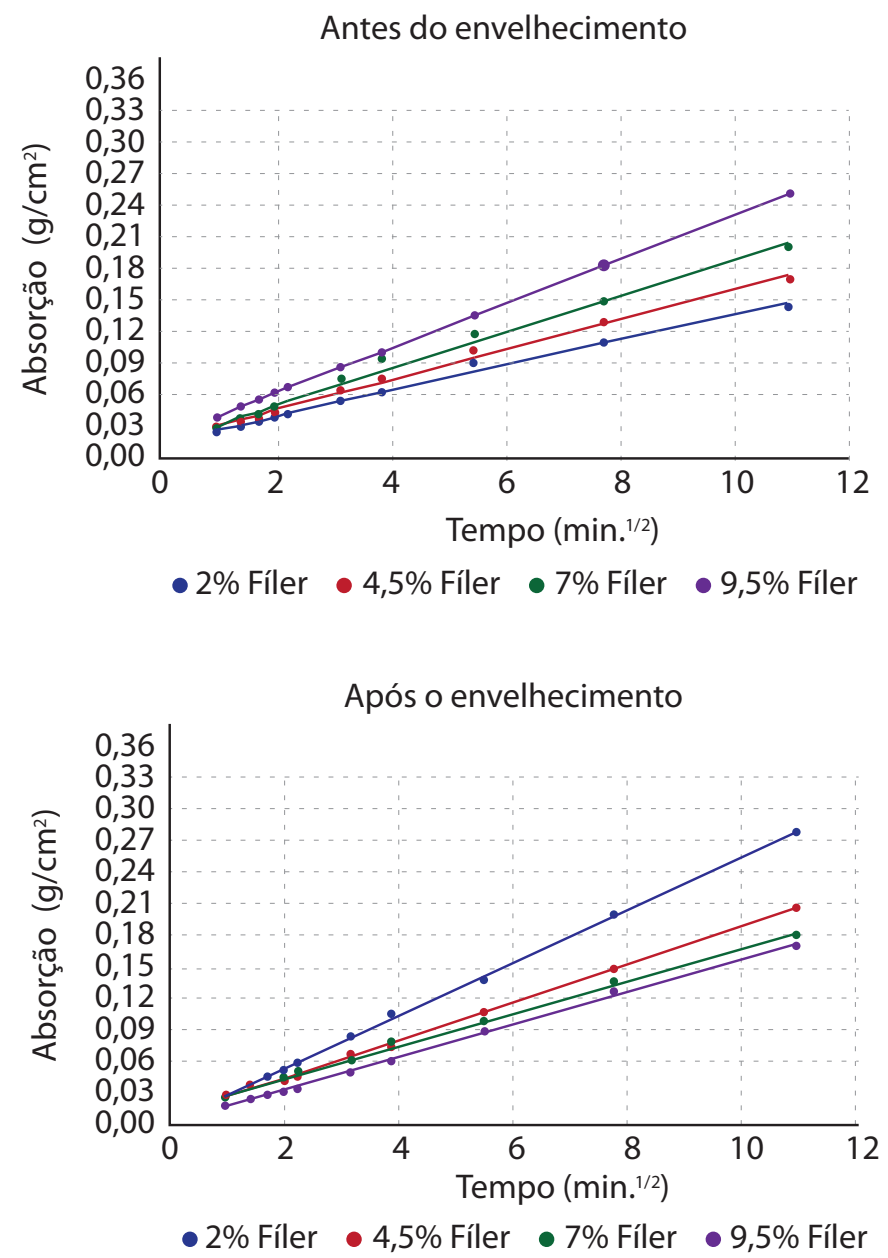

Figura 4. Absorção por capilaridade dos revestimentos antes (acima) e após (abaixo) o envelhecimento acelerado por ciclos térmicos. 
Os resultados demonstram um aumento no volume de poros capilares em praticamente todos os traços de revestimento utilizados (exceto no traço com 9,5\% de filer). Apesar do aumento de poros capilares ser coerente com a degradação dos revestimentos, verifica-se que o método não consegue avaliar adequadamente o nível de degradação dos revestimentos. Os valores de capilaridade não permitiram uma distinção entre os exemplares ciclados e náo ciclados.

- Na tabela 4, podem ser visualizados os valores de resistência de aderência obtidos antes e após o ensaio acelerado.

Tabela 4. Médias das resistências de aderência dos revestimentos.

\begin{tabular}{lllll}
\hline $\begin{array}{l}\text { teor de } \\
\text { fíler }\end{array}$ & Antes do envelhecimento & \multicolumn{2}{l}{ Após o envelhecimento } \\
\cline { 2 - 5 }$(\%)$ & $\begin{array}{l}\text { número } \\
\text { de leituras }\end{array}$ & $\begin{array}{l}\text { Resistência de aderência } \\
\text { e Coeficiente de Variação } \\
(\mathrm{MPa})\end{array}$ & $\begin{array}{l}\text { número de } \\
\text { leituras }\end{array}$ & $\begin{array}{l}\text { Resistência de aderência } \\
\text { e Coeficiente de Variação } \\
(\mathrm{MPa})\end{array}$ \\
\hline 2,0 & 12 & $0,88(0,17)$ & 12 & $0,93(0,27)$ \\
\hline 4,5 & 12 & $0,94(0,32)$ & 13 & $0,92(0,27)$ \\
\hline 7,0 & 13 & $0,77(0,30)$ & 11 & $0,54(0,26)$ \\
\hline 9,5 & 12 & $0,94(0,21)$ & 16 & $0,57(0,31)$ \\
\hline
\end{tabular}

A avaliação do desempenho dos revestimentos a partir dos resultados de resistência de aderência foi pouco conclusiva. Embora tenham sido previstos 18 ensaios em cada revestimento, foi possível determinar somente o valor da resistência de aderência em cerca de $3 / 4$ destes ensaios, em função de problemas durante a realização do corte com disco diamantado, atividade prévia ao ensaio de tração. Apesar disso, o número de exemplares restantes foi sempre superior ao especificado pela norma. A despeito dos cuidados tomados na execução do revestimento e durante o ensaio, os coeficientes de variação foram relativamente elevados (na ordem de 0,27 MPa, ou 33\% da resistência de aderência média), fato que pode ter sido influenciado pelo uso de filer de concreto na composição da argamassa.

Aparentemente, existe uma queda de resistência de aderência nos revestimentos com teores mais altos de adição de filer, porém os coeficientes de variação obtidos não permitem uma conclusão consistente. 
- Na tabela 5, podem ser visualizados a incidência de cada forma de ruptura antes e após o ensaio acelerado.

Tabela 5. Incidência da forma de ruptura.

\begin{tabular}{lllll}
\hline Característica & $\begin{array}{l}\text { Argamassa } \\
(\%)\end{array}$ & $\begin{array}{l}\text { Interface Arg./ } \\
\text { chap. } \\
(\%)\end{array}$ & $\begin{array}{l}\text { Interface Chap.// } \\
\text { subst. } \\
(\%)\end{array}$ & $\begin{array}{l}\text { Substrato } \\
(\%)\end{array}$ \\
\hline Não ciclado & 46,72 & 42,44 & 10,23 & 0,60 \\
\hline Após ciclagem & 58,03 & 37,40 & 4,43 & 0,14 \\
\hline
\end{tabular}

A exposição a ciclos térmicos alterou a forma de ruptura nos ensaios de resistência de aderência, havendo um acréscimo na quantidade de rupturas coesivas na argamassa, o que demonstra que a área que sofreu maior degradação foi o revestimento de argamassa. Esse fenômeno, para os materiais utilizados no programa experimental, superou o efeito do esforço de cisalhamento decorrente de movimentaçáo diferencial entre a argamassa e o substrato ao longo dos ciclos térmicos.

- A deterioração da argamassa de revestimento é comprovada a partir da estimativa do volume de vazios da argamassa, que consta na Tabela 6:

Tabela 6. Estimativa da quantidade de vazios nas argamassas de revestimento.

\begin{tabular}{lll}
\hline Teor de fíler (\%) & Antes do envelhecimento & Após o envelhecimento \\
\hline 2,0 & 8,86 & 18,54 \\
\hline 9,5 & 22,93 & 25,84 \\
\hline
\end{tabular}

Observa-se que, nos dois traços avaliados, houve um aumento na quantidade de vazios do revestimento, corroborando a hipótese de deterioração do revestimento em função dos ciclos térmicos.

As determinaçóes de velocidade de onda ultrassônica não apresentaram diferenças significativas entre os exemplares ciclados e não ciclados. Esse fato demonstra que o tamanho das fissuras geradas nos revestimentos é inferior à amplitude da onda ultrassônica utilizada, e que os parâmetros adotados para o ensaio não apresentaram sensibilidade suficiente para esta análise. 
- Na Tabela 7, são visualizados os valores médios de dureza superficial, obtidas com uso de durômetro Shore D.

Tabela 7. Média dos resultados de dureza superficial por durômetro Shore D.

\begin{tabular}{lll}
\hline Teor de fíler (\%) & Antes do envelhecimento & Após o envelhecimento \\
\hline 2,0 & 75 & 70 \\
4,5 & 77 & 69 \\
7,0 & 77 & 71 \\
\hline 9,5 & 78 & 69 \\
\hline
\end{tabular}

Em todos os revestimentos houve uma queda de dureza superficial, em consequência do ensaio de envelhecimento.

Tendo em consideração os resultados obtidos, pode-se constatar que uma adequada avaliação da degradação do revestimento exige a realização de ensaios não previstos nas normas que especificam o procedimento de envelhecimento acelerado, como a NBR 15575-4. Os ensaios utilizados para a avaliação devem ser escolhidos de modo a permitir a avaliação das alteraçóes nas propriedades dos revestimentos em função da exposição aos ciclos térmicos.

A respeito das propriedades avaliadas neste programa experimental, podemos tecer as seguintes consideraçôes:

- a avaliação da superfície do revestimento por meio da visualização de fissuras ou deterioração superficial é um parâmetro para a avaliação do fim da vida útil de um revestimento, mas não permite uma avaliação de danos que ocorrem em nível de microestrutura do sistema ao longo do processo;

- a determinação da resistência de aderência segundo a NBR 13528 (ABNT, 2010) é um parâmetro qualitativo valioso para a avaliação da durabilidade, porém apresenta grande dispersão de resultados (que pode ser ampliada com a adição de resíduos), o que muitas vezes impede a obtenção de resultados conclusivos; a avaliação da forma de ruptura é um fator complementar que pode trazer informaçóes importantes sobre a deterioração da argamassa de revestimento; 
- a determinação da capilaridade e do teor de água absorvida pelo sistema complementam os ensaios de resistência de aderência, porém apresentam elevada dispersão de resultados;

- a estimativa do volume de vazios permite avaliar o dano decorrente do envelhecimento acelerado e pode ser um importante instrumento neste sentido;

- a dureza superficial permite a determinaçáo da existência de dano na superfície, decorrente dos ciclos térmicos, porém, no caso em questão, não foi suficiente para distinguir os revestimentos entre si e não apresentou relação com os demais resultados.

\section{Conclusão}

A estimativa da durabilidade de revestimentos de argamassa com incorporação de resíduos é complexa e exige a realização de diversos ensaios simultâneos. No Brasil, o método normalizado para a realização da degradação é descrito no anexo D da NBR 15.575-4, que propóe a realização de um ensaio acelerado com ciclos contínuos de aquecimento com painel radiante e resfriamento por meio de choque térmico decorrente da aspersão de água. A norma especifica que sistemas que não apresentem danos visíveis na superfície e deformaçóes excessivas após 10 ciclos tem desempenho adequado para a construção de edifícios, porém não gera dados que permitam a comparação do nível de degradação dos revestimentos ou uma estimativa de vida útil para o sistema. Procurando contribuir para o desenvolvimento de uma metodologia de avaliação mais ampla, foram propostos diversos métodos de ensaio para a comparação dos revestimentos antes e após a ciclagem, contemplandose parâmetros mecânicos (resistência de aderência e tipo de ruptura no arrancamento, dureza superficial), físico (absorção de água por capilaridade) e de estrutura interna da argamassa (volume de vazios). Verificou-se que o uso exclusivo de um único parâmetro de avaliação dificilmente permitirá uma avaliação conclusiva sobre o desempenho do sistema.

\section{Agradecimentos}

Os autores agradecem à FINEP pelo auxílio concedido para a execução da parte experimental deste trabalho. 


\section{Referências Bibliográficas}

ANDRADE, C. Manual para diagnóstico de obras deterioradas por corrosão de armaduras. 1 ed. Tradução e adaptação: Antônio Carmona e Paulo Helene. Editora PINI, 1992.

AMERICAN SOCIETY FOR TESTING AND MATERIALS C1579 - Standard Method for Evaluating Plastic Shrinkage Cracking of Restrained Fiber Reinforced Concrete (Using a Steel Form Insert).

AMERICAN SOCIETY FOR TESTING AND MATERIALS D5590-00 - Standard test method for determining the resistance of paint films and related coatings to fungal defacement by accelerated four-week Agar plate assay.

ASSOCIAÇÃO BRASILEIRA DE NORMAS TÉCNICAS. NBR 15575-4- Edificaçôes habitacionais - Desempenho Parte 4: Requisitos para os sistemas de vedaçóes verticais internas e externas - SVVIE. Rio de Janeiro, 2013.

ASSOCIAÇÃO BRASILEIRA DE NORMAS TÉCNICAS. NBR 13749 - Revestimento de paredes e tetos de argamassas inorgânicas - Especificação. Rio de Janeiro, 2013.

ASSOCIAÇÃO BRASILEIRA DE NORMAS TÉCNICAS. NBR 13528 - Revestimento de paredes e tetos de argamassas inorgânicas - Determinação da resistência de aderência à traçáo. Rio de janeiro, 2010.

ASSOCIAÇÃO BRASILEIRA DE NORMAS TÉCNICAS. NBR 15630 - Argamassa para assentamento e revestimento de paredes e tetos - Determinação do módulo de elasticidade dinâmico através da propagaçáo de onda ultrassônica. Rio de Janeiro, 2008.

ASSOCIAÇÃO BRASILEIRA DE NORMAS TÉCNICAS. NBR 15630 - Argamassa para assentamento e revestimento de paredes e tetos - Determinação do módulo de elasticidade dinâmico através da propagação de onda ultra-sônica. Rio de Janeiro, 2008.

ASSOCIAÇÃO BRASILEIRA DE NORMAS TÉCNICAS. NBR 13281 - Argamassa para assentamento e revestimento de paredes e tetos - requisitos. Rio de Janeiro, 2005.

ASSOCIAÇÃO BRASILEIRA DE NORMAS TÉCNICAS. NBR 15259/05 - Argamassa para assentamento e revestimento de paredes e tetos - Determinaçáo da absorçáo de água por capilaridade e do coeficiente de capilaridade. Rio de Janeiro, 2005.

ASSOCIAÇÃO BRASILEIRA DE NORMAS TÉCNICAS. NBR 13279 - Argamassa para assentamento e revestimento de paredes e tetos - Determinaçáo da resistência à tração na flexão e à compressão. Rio de Janeiro, 2005.

BONIN, L. C.; CARASEK, H.; CINCOTTO, M. A.; SOUZA, U. E. L. Massa critica pela qualidade. In: Téchne. 41 ed. São Paulo: Editora PINI, julho 1999.

CARASEK, H. Avaliaçâo de resultados do ensaio de resistência de aderência de revestimentos de argamassa. Téchne, n. 185, 2012. disponível em: http://techne.pini.com.br/engenhariacivil/185/artigo286939-1.aspx

CARASEK, H. Argamassas. In: ISAIA, G. C. (Ed.). Materiais de Construção Civil e princípios de ciência e engenharia de materiais. Sáo Paulo: IBRACON, 2010. v. 2, p. 893-944. 
CARÉ, S. Effect of temperature on porosity and on chloride diffusion in cement pastes. Construction and Building Materials 22, p. 1560-1573, 2008.

CASCUDO, O.; CARASEK, H. Ação da Carbonatação no Concreto. In: ISAIA, G. C. (Ed.). Concreto: Ciência e Tecnologia. São Paulo: IBRACON, 2011. v. 1, p. 849-885.

CIB Report 64 - Working with the performance approach in building, CIB W60, (1980). 30p.

European Standard. EN 1015-19: Methods of test for mortar for masonry Part 19: Determination of water vapour permeability of hardened rendering and plastering mortars. 2000

European Standard. UNE-EN 13687-2: Productos y sistemas para la protección y reparación de estructuras de hormigón. Métodos de ensayo. Determinación de la compatibilidad térmica. Parte 2: Ciclos de enfriamiento brusco a partir de una temperatura elevada. 2002, 10p.

European Standard. prEN 16306 : Méthodes d'essai pour les pierres naturelles. Détermination de la résistance des marbres aux cycles thermiques et à l'humidité. 2012.

FAURE, P.; CARÉ, S. Application of NMR relaxation and MRI characterization to the determination of porosity and water content in cement pastes subjected to drying. Cement and Concrete Research. 2011.

FERREIRA, B. B. D. Tipificação de patologias em revestimentos argamassados. Dissertação (Mestrado) - Universidade Federal de Minas Gerais, Belo Horizonte. 2010.

FOLIENTE, G. C. Developments in performance-based building codes and standards. Forest products journal, vol. 50, n. 7/8, p. 12-21, 2000.

GHABEZLOO, S. Micromechanics analysis of thermal expansion and thermal pressurization of hardened cement paste. Cement and Concrete Research, 2011.

ISO 6241 - Performance standards in building - Principles for their preparation and factors to be considered. 1984.

KIM, K.; JEON, S.; KIM, J.; YANG, S. An experimental study on thermal conductivity of concrete. Cement and Concrete Composites, Essex, n. 33, p. 363-371, 2003.

LIMA, M. G. Açóes do Meio Ambiente sobre as Estruturas de Concreto. In: ISAIA, G. C. (Ed.). Concreto: Ciência e Tecnologia. São Paulo: IBRACON, 2011. v. 1 , p. 733-772.

MEHTA, P. K.; Monteiro, P. R. M. Concreto: Microestrutura, Propriedades e Materiais. Editora Ibracon, 2008.

MEYERS, S. L. Thermal coefficient of expansion of Portland cement: long time tests. Ind Eng Chem, 32, p. 1107-12, 1940.

OLIVEIRA, L. A.; MOREIRA, T. M.; MITIDIERI FILHO, C. V. Estanqueidade de fachadas à água da chuva. Revista de Tecnologia das Construçôes - Techne. no 106, jan. 2005. Ed. Pini. Sáo Paulo. 
PEREZ, A. R. Umidade nas Edificaçóes: recomendaçôes para a prevenção da penetração de água pelas fachadas (1 ${ }^{a}$ parte). São Paulo. PINI. Instituto de Pesquisas Tecnológicas, Divisão de Edificações - IPT. 1988. p. 571-578.

RILEM Test Method no 11.4 - Measurement of water absorption under low pressure.

RILEM TC 166-PCD: Permeability of concrete as a criterion of its durability. Materials and structures, vol 32, 1999, p163-173. P PCD: Permeability of Concrete as a Criterion of RILEM TC 183-MIB Microbial impact on building materials: Weathering and conservation - Techniques applied to the study of microbial impact on building materials SHIRAKAWA, M. A.; CINCOTTO, M. A.; GAMBALE, W. Influência do crescimento de fungos na carbonatação de argamassas. In: VII Simpósio Brasileiro de Tecnologia de argamassas. Anais. Recife: ANTAC, 2007.

SCHULSON E. M.; SWAINSON I. P.; HOLDEN T. M. Internal stress within hardened cement paste induced through thermal mismatch calcium hydroxide versus calcium silicate hydrate. Cem Concr Res, 31, p. 1785-91, 2001.

SILVA, N. G.; GLEIZE, J. P.; GOMES, L. A. Metodologia para avaliação da fissuração em revestimentos de argamassa. In: VIII Simpósio Brasileiro de Tecnologia de argamassas. Anais, Curitiba: ANTAC, 2009.

QIANG, Z; KEFEI, L.; TEDDY, F.; PATRICK, D. Effect of porosity on thermal expansion coefficient of cement pastes and mortars. Construction and Building Materials, 28, p. 468-475, 2012. 
